НАУКОВИЙ ВІСНИК

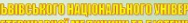

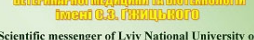

cientific messegger of Livi National University
Veterinary Medicine and Biotechnologies

Twand

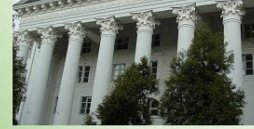

(1)

Том 21 № 91

2019
Науковий вісник Дьвівського національного університету ветеринарної медицини та біотехнологій імені С.3. Гжицького. Серія: Сільськогосподарські науки

Scientific Messenger of Lviv National University of Veterinary Medicine and Biotechnologies. Series: Agricultural sciences

UDC 633.2: 633.25

\title{
Productivity and biochemical composition of feeds of grasses and herbage legumes, depending on fertilizers and growth stimulators
}

\author{
L.K. Savchuk, I.V. Vyhovsky
}

Rivne State Humanitarian University, Rivne, Ukraine

Article info

Received 07.09.2019

Received in revised form 07.10 .2019

Accepted 08.10.2019

Rivne State Humanitarian University, Stepan

Bandera Str., 12, Rivne, 33028

Ukraine.

Tel.: +38-067-907-21-48

E-mail: lubasav4uk@gmail.com, vugovsky@ukr.net

Savchuk, L.K., \& Vyhovsky, I.V. (2019). Productivity and biochemical composition of feeds of grasses and herbage legumes, depending on fertilizers and growth stimulators. Scientific Messenger of Lviv National University of Veterinary Medicine and Biotechnologies. Series: Agricultural sciences, 21(91), 49-53. doi: 10.32718/nvlvet-a9108

The main task of increasing the productivity of perennial grass-legumes grown on the slopes withdrawn from cultivation is to form optimal conditions for the growth and development of meadow grasses, which would ensure the highest yield of forage during the entire period of use of grass and the production of highquality and cheap feed for public livestock. To successfully solve the problem of productivity of agrophytocenoses in scientific and practical applications, it is important to know exactly how the relationship of plants in the process of their joint growth and development, what changes occur in the chemical composition of feed when applying mineral fertilizers and growth promoters on eroded lands with steepness $6-7^{\circ}$ under soil sedimentation of the research sites of the Rivne Institute of Agricultural Industry of NAAS of Ukraine. The results of research are presented, which showed that it is economically more effective on the slopes to grow cereals and legumes with a longer period of productive longevity, while using low rates of nitrogen fertilizers, which promotes the formation of phytocenosis, which is dominated by valuable species of cereals and perennial legumes. sowing). The introduction of mineral fertilizers and growth promoters had a positive effect on the biochemical composition of cereals. The results of studies have shown that for the creation of cereals and leguminous herbs hay use in a non-coating way, you must sow a grass mix, which includes the following herbs: alfalfa sowed (4.4 million pieces per hectare) + long beetroot horned (4.4 million pieces per hectare) + bromus inermis (3.4 million pieces per hectare) + lolium perenne (3.4 million pieces per hectare) of conditioned seeds that affect the productivity and chemical composition of the herb during the growing season. On the basis of the conducted researches it is established that the influence of different doses of mineral fertilizers and growth promoters (emistim C and fumar) significantly increases the yield of dry weight and biochemical composition of feed. The results of the research are presented, which showed that during the years of the formation of cereals and leguminous grass hay use, the highest yield of dry fodder $(7.5 \mathrm{t} / \mathrm{ha}$ ) was collected in the variant, where mineral fertilizers were calculated at the rate of $N_{60} P_{60} K_{90}$ with the use of fumarant plant growth stimulator and high quality, the yield of feed units was $5.25 \mathrm{t} / \mathrm{ha}$, and digestible protein $0.82 \mathrm{t} / \mathrm{ha}$. Years of research have shown that it is advisable to use low rates of mineral fertilizers $\left(N_{60} P_{60} K_{90}\right)$ and growth stimulants emistim $C$ and fumar to improve feed quality. feed.

Key words: hayfields, eroded slopes, meadows, fertilizers, growth promoters, chemical composition of

\section{Продуктивність та біохімічний склад корму лучної травосумішки залежно від удобрення та стимуляторів росту}

Л.К. Савчук, І.В. Виговський

Рівненський державний гуманітарний університет, м. Рівне, Украӥна 
Основним завданням підвищення продуктивності багаторічних злаково-бобових травостої, вирощених на схилах, виведених із обробітку, є формування оптимальних умов росту і розвитку лучних трав, які б забезпечили найвищу урожайність корму протягом усього періоду користування травостою та виробництва високоякісних і дешевих кормів для громадського тваринниитва. Для успішного вирішення проблеми продуктивності агрофітоценозів у науковому та практичному луківництві важливо знати, як саме складаються взаємовідносини рослин у проиесі їх сумісного росту та розвитку, які зміни відбуваються у хімічному складі корму при внесенні мінеральних добрив та стимуляторів росту на еродованих землях крутизною 6-7º, виведених під залуження грунтах дослідних ділянок Рівненського інституту агропромислового виробниитва НААН Украӥни. Подано результати досліджень, які засвідчил, що економічно дочільніше на схилах вирощувати злаково-бобові травосумішки з довщим періодом продуктивного довголіття, використовуючи при изьму невисокі норми азотних добрив, щчо сприяє утворенню фітоценозу, в якому переважають цінні види злакових та багаторічні бобові трави (лядвенець рогатий та люиерна посівна). Позитивний вплив на біохімічний склад злаково-бобового травостою мало внесення мінеральних добрив та стимуляторів росту. Наведені результати досліджень показали, щуо для створення злаково-бобового травостою сінокісного використання безпокривним способом потрібно висівати травосумішку, до складу якої введено такі трави: люиерна посівна (4,4 млн шт./га) + лядвенець рогатий (4,4 млн шт./га) + стоколос безостий (3,4 млн шт./га) + пажитниця багатоукісна (3,4 млн ит./га) кондиційного насіння, які впливають на продуктивність $i$ хімічний склад травостою протягом вегетачійного періоду. На основі проведених досліджень встановлено, ияо вплив різних доз мінерального удобрення та стимуляторів росту (емістиму С і фумару) суттєво збільшує урожайність сухої маси та біохімічний склад корму. Подано результати досліджень, які засвідчили, що за роки формування злаково-бобового травостою сінокісного використання найвищий урожай сухого корму $(7,5 \mathrm{~m} / 2 a)$ зібрано на варіанті, де вносили мінеральні добрива з розрахунку $N_{60} P_{60} K_{90} 3$ використанням стимулятора росту рослин фумару та високою його якістю, вихід кормових одиниць становив 5,25 m/га, а перетравного протеїну - 0,82 m/2а. За роки дослідження встановлено, щзо для поліпшення якісних показників корму доцільно використовувати невисокі норми мінеральних добрив ( $\left.{ }_{60} P_{60} K_{90}\right)$ та стимулятори росту емістим C $i$ фумар.

Ключові слова: сінокоси, еродовані схили, лучні трави, удобрення, стимулятори росту, хімічний склад корму.

\section{Вступ}

Внаслідок освоєння родючості земель на території Лісостепу західного склалася ситуація, коли рівень розораності сільськогосподарських угідь досяг 70\% у всій зоні, а в окремих регіонах $-80-85 \%$ і більше. Тому останніми роками зростає частка грунтів, які частково або сильно еродовані. На схилових землях найефективнішими в кормовиробництві $\epsilon$ низькозатратні системи, які передбачають використання довготривалих лучних травостоїв і мають високий біологічний потенціал (Abramovych, 2004; Lavres et al., 2004; Lüscher et al., 2014; Savchuk \& Vyhovsky, 2018; Vyhovsky, 2018).

За умов загострення проблеми енергозбереження сільського господарства, погіршення матеріальнотехнічної бази, найвищої у світі розораності сільськогосподарських угідь зростає кількість деградованих земель у Рівненській області, площу яких потрібно значно зменшити за рахунок залуження. Все це негативно впливає на розвиток тваринництва та кормовиробництва, в якому провідну роль повинні відігравати злаково-бобові багаторічні трави та удобрення на сіножатях і пасовищах (Sayko, 2000; Gulwa et al., 2018). В лабораторії луківництва Інституту землеробства i тваринництва західного регіону проводили дослідження із створенням сіяних сінокосів та пасовищ на еродованих схилах в умовах західного Лісостепу 3 використанням у складі травосумішок таких бобових компонентів, як конюшина лучна, гібридна та повзуча, а також лядвенцю рогатого. Ці травосумішки дають можливість отримувати 4,05-4,94 т/га сухої маси пасовищного корму або 4,80-5,94 т/га сіна (Stefanyshyn, 2002). Найменш затратними в групі кормових культур є бобові багаторічні трави, зокрема у разі вирощування ї на еродованих землях (Mashchak, 2011). Як свідчить світовий дослід, залуження та удобрення сильно еродованих земель багаторічними травами і травосумішками підвищує продуктивність екосистеми, стабілізує їі функціонування, поліпшує екологічне становище (Biruk, 1998).

Для громадського тваринництва було, $\epsilon$ i залишається надзвичайно актуальною проблемою виробництво високоякісних і дешевих кормів. На даний час питання використання стимуляторів росту та удобрення рослин, які на різних етапах онтогенезу підвищують врожайність та якість лучного корму, $є$ актуальним (Volkohon, 2001). Тому створення оптимальних умов для росту та розвитку лучних трав має важливе значення для одержання високого врожаю корму та його якості.

\section{Матеріал і методи досліджень}

Експериментальні дослідження проводили на темно-сірих опідзолених легкосуглинкових, середньозмитих, виведених під залуження грунтах дослідних ділянок Рівненського інституту агропромислового виробництва НААН України на схилі південнозахідної експозиції крутизною 6-7 ${ }^{\circ}$.

Для створення злаково-бобового травостою сінокісного використання безпокривним способом висівали травосумішку, до складу якої було введено такі трави: люцерна посівна (4,4 млн шт./га) + лядвенець рогатий (4,4 млн шт./га) + стоколос безостий (3,4 млн шт./га) + пажитниця багатоукісна (3,4 млн шт./га). Польові дослідження проводили за методикою Інституту кормів НААН України (Ваbych, 1994). Аналізи хімічного складу корму - за методикою О.В. Петербургського (Peterburhskyy, 1968). Поживність корму вираховували в кормових одиницях, виходячи з одержаних результатів хімічного аналізу, враховуючи вміст білка, жиру, клітковини і БЕР, з використанням коефіцієнтів їх перетравності. Експериментальні дослідження проводили на закладеному весною досліді 3 вивчення впливу удобрення і стимуляторів росту на продуктивність злаково-бобової травосумішки.

Схема досліду: 1 - Контроль - без удобрення, 2 $\mathrm{P}_{30} \mathrm{~K}_{60}, 3-\mathrm{P}_{60} \mathrm{~K}_{90}, 4-\mathrm{N}_{60} \mathrm{P}_{60} \mathrm{~K}_{90}, 5-\mathrm{P}_{60} \mathrm{~K}_{90}+$ емістим $\mathrm{C}$, $6-\mathrm{P}_{60} \mathrm{~K}_{90}+$ фумар, $7-\mathrm{N}_{60} \mathrm{P}_{60} \mathrm{~K}_{90}+$ фумар. Варіанти 
досліду удобрювали згідно зі схемою. У досліді використовували подвійні і потрійні комбінації мінеральних добрив. Азотні добрива вносили в дозі $\mathrm{N}_{30}$ весною і після другого укосу. Фосфорні і калійні - навесні. Робочий розчин стимуляторів росту емістиму $\mathrm{C}$ i фумару готували за методикою Пономаренка (Ponomarenko, 1986). Погодні умови в роки проведення досліджень були сприятливими для вирощування багаторічних трав, хоча в літні періоди спостерігали недостатню кількість опадів.

\section{Результати та їх обговорення}

В усіх природно-кліматичних зонах найбільший вплив на продуктивність та біохімічний склад корму мають мінеральні добрива, насамперед азотні (Dehodyuk, 1986).

При обмежених запасах Азоту в грунті, але надходження достатньої кількості Калію і Фосфору між бобовими та злаковими встановлюється рівновага i вони можуть тривалий час брати участь у формуванні врожаю. Незважаючи на те, що бобові здатні забезпе- чувати себе Азотом унаслідок симбіозу з бульбочковими бактеріями, вони в польових умовах зазвичай менш конкурентоспроможні, ніж злаки, у боротьбі за доступний калій і фосфор, воду і світло. Це пояснюється меншою кількістю бобових і довжиною їх кореневих волосків порівняно зі злаками (Yarmolyuk et al., 2010). Тому застосування стимуляторів росту з раціональним удобренням $\epsilon$ високоефективним заходом біологізації кормовиробництва.

Одним із можливих методів зниження затрат при створенні сіножатей на схилових землях і виробництві 3 них кормів, як свідчать раніше проведені дослідження, є підбір травосумішок, адаптованих до місцевих умов кормових культур (Bohovin, 2005).

Багаторічні трави, маючи різний генетичний та фітоценотичний потенціал, перебуваючи в однакових екологічних умовах, беруть різну участь у формуванні травостою залежно від складу травосумішки.

Дослідженнями встановлено, що існує залежність урожайності злаково-бобового травостою від внесення мінеральних добрив та стимуляторів росту (рис. 1).

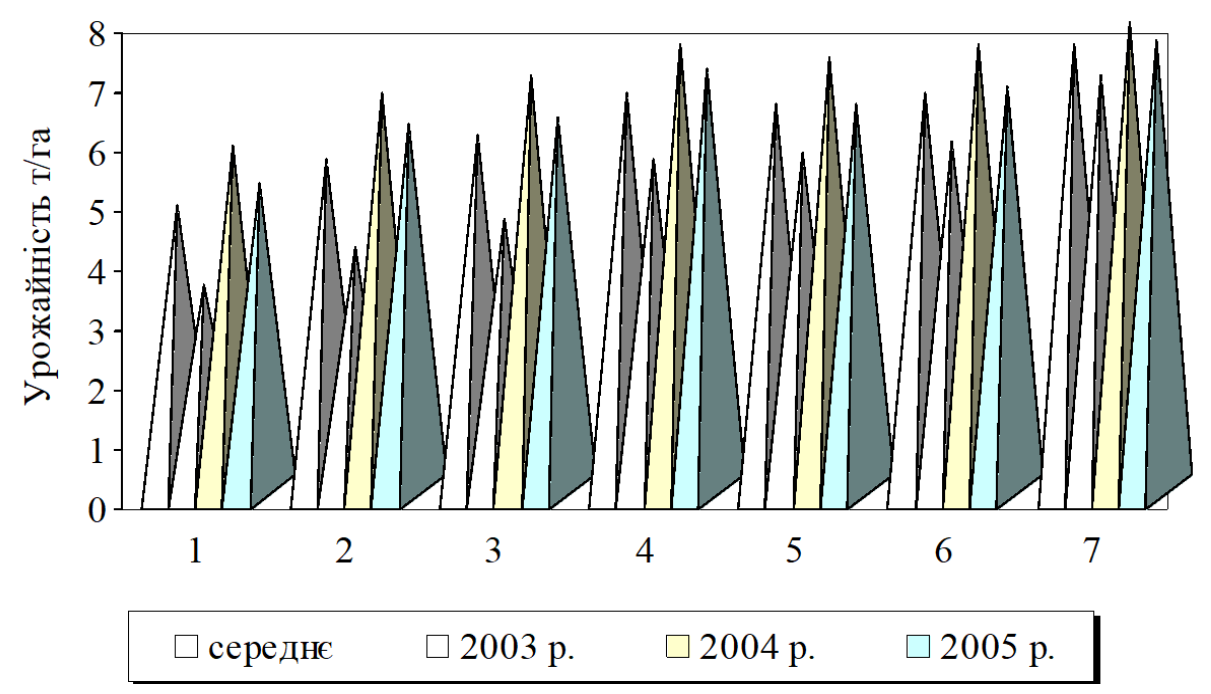

Рис. 1. Урожайність злаково-бобового травостою від внесення мінеральних добрив та стимуляторів росту. Варіанти досліду: 1 - контроль без удобрення, $2-\mathrm{P}_{30} \mathrm{~K}_{60}, 3-\mathrm{P}_{60} \mathrm{~K}_{90}, 4-\mathrm{N}_{60} \mathrm{P}_{60} \mathrm{~K}_{90}, 5-\mathrm{P}_{60} \mathrm{~K}_{90}+$ емістим C, $6-\mathrm{P}_{60} \mathrm{~K}_{90}+$ фумар, $7-\mathrm{N}_{60} \mathrm{P}_{60} \mathrm{~K}_{90}+$ фумар

На контролі без удобрення в середньому за роки використання зібрано 4,8 т/га сухого корму. Застосування фосфорних $\mathrm{i}$ калійних добрив у нормі $\mathrm{P}_{30} \mathrm{~K}_{60}$ забезпечило приріст урожаю сухої маси на 0,8 т/га порівняно $з$ контролем. Приріст до контролю на варіантах 3 удобренням $\mathrm{P}_{60} \mathrm{~K}_{90}$ становив 1,2 т/га сухої маси. Додаткове внесення азотних добрив у дозі $\mathrm{N}_{60}$ на фосфорно-калійному фоні $\left(\mathrm{P}_{60} \mathrm{~K}_{90}\right)$ збільшило приріст урожаю порівняно з контролем на 1,9 т/га сухої маси.

За роки формування злаково-бобового травостою сінокісного використання, який складався із люцерни посівної, лядвенцю рогатого, стоколосу безостого, пажитниці багатоукісної, найвищий врожай сухої маси (7,5 т/га) зібрано на варіанті, де вносили мінера- льні добрива 3 розрахунку $\mathrm{N}_{60} \mathrm{P}_{60} \mathrm{~K}_{90} 3$ використанням стимулятора росту рослин фумару.

Внесення фосфорних i калійних добрив у дозі $\mathrm{P}_{60} \mathrm{~K}_{90}$ разом із стимуляторами росту емістимом $\mathrm{C}$ i фумаром забезпечили приріст урожаю сухої маси відповідно на 1,7 і 1,9 т/га та 0,5 і 0,7 т/га порівняно 3 варіантом, де вносили тільки фосфорно-калійні добрива у нормі $\mathrm{P}_{60} \mathrm{~K}_{90}$.

Виходячи 3 того, що на показники урожайності злаково-бобового травостою значний вплив мали мінеральні добрива, нами було розраховано кореляційну залежність урожаю сухої маси від норми мінеральних добрив. Згідно з розрахунками рівняння регресії має такий вигляд:

$$
\mathrm{y}=0,01 \mathrm{x}+4,78
$$


Процес формування врожаю злаково-бобового травостою достовірно описує наведене рівняння, оскільки тіснота зв'язку між результуючою ознакою та аргументами висока. Про це свідчать коефіцієнт лінійної кореляції $(\mathrm{r}=0,99)$ та коефіцієнт детермінації $\mathrm{d}=99,1 \%$.

Отже, крім удобрення злаково-бобового травостою на схилових землях Азотом, Фосфором і Калієм необхідно використовувати стимулятори росту рослин. Враховуючи особливості стимуляторів росту, пропонується в системі мінерального удобрення рослин орієнтуватись на обов'язкове використання цих речовин у сучасних технологіях вирощування лукопасовищних трав на схилових землях, що дасть можливість знизити дози мінеральних добрив без зменшення врожайності, а також уникнути ризику забруднення високими нормами кормів та довкілля.

Достатній вміст у зеленій масі бобових трав, мінерального удобрення, стимуляторів росту та використання сінокісного травостою в оптимальні строки позитивно вплинули на поживність корму (табл. 1).

\section{Таблиця 1}

Продуктивність лучних травостоїв залежно від удобрення та стимуляторів росту

\begin{tabular}{lccccc}
\hline \multicolumn{1}{c}{ Варіанти досліду } & Суха маса, & \multicolumn{2}{c}{ Приріст до контролю } & \multicolumn{3}{c}{ Вихід 3 1 га, т } \\
\cline { 1 - 1 } \multicolumn{1}{c}{ Удобрення } & т/га & т/га & $\%$ & кормових одиниць & перетравного протеїну \\
\hline Без удобрення (контроль) & 4,8 & - & - & 3,66 & 0,47 \\
$\mathrm{P}_{30} \mathrm{~K}_{60}$ & 5,6 & 0,8 & 17 & 4,27 & 0,59 \\
$\mathrm{P}_{60} \mathrm{~K}_{90}$ & 6,0 & 1,2 & 25 & 4,57 & 0,65 \\
$\mathrm{~N}_{60} \mathrm{P}_{60} \mathrm{~K}_{90}$ & 6,7 & 1,9 & 40 & 4,75 & 0,67 \\
$\mathrm{P}_{60} \mathrm{~K}_{90}+$ емістим С & 6,5 & 1,7 & 35 & 5,0 & 0,72 \\
$\mathrm{P}_{60} \mathrm{~K}_{90}+$ фумар & 6,7 & 1,9 & 40 & 5,15 & 0,75 \\
$\mathrm{~N}_{60} \mathrm{P}_{60} \mathrm{~K}_{90}+$ фумар & 7,5 & 2,7 & 56 & 5,25 & 0,82 \\
\hline \multicolumn{1}{c}{$\mathrm{H}$} & & & & &
\end{tabular}

Вихід кормових одиниць на варіантах становив 3,66-5,25 т/га. Як видно з одержаних результатів наших досліджень, на варіанті, де вносили повне мінеральне удобрення в дозі $\mathrm{N}_{60} \mathrm{P}_{60} \mathrm{~K}_{90} 3$ додаванням стимулятора росту фумару, одержано найвищий вихід кормових одиниць (5,25 т/га).

На варіанті, де застосовували мінеральні добрива в дозі $\mathrm{N}_{60} \mathrm{P}_{60} \mathrm{~K}_{90}$, вихід кормових одиниць становив на 0,5 т/га менше. При внесенні фосфорних і калійних добрив разом зі стимуляторами росту (емістимом $\mathrm{C}$ i фумаром) збір кормових одиниць був дещо вищим (5,0 і 5,15 т/га), ніж на варіанті, де застосовували лише фосфорно-калійні добрива в дозі $\mathrm{P}_{60} \mathrm{~K}_{90}(4,57$ т/га).

Аналіз одержаних даних хімічного складу корму показував, що урожайна маса сіяних злаково-бобових травостоїв за роки досліджень добре забезпечена органічними поживними речовинами і за загальним рівнем вмісту їх в кормі, в основному, відповідала зоотехнічним нормам годівлі великої рогатої худоби. Суха маса злаково-бобового травостою достатньо забезпечена перетравним протеїном. За концентрацією сирого протеїну в сухій речовині корму нормується рівень живлення для ВРХ. У злаково-бобовому травостої при мінеральному удобренні і використанні стимуляторів росту найбільше сирого протеїну виявлено на варіантах досліду, де вносили $\mathrm{N}_{60} \mathrm{P}_{60} \mathrm{~K}_{90} 3$ додаванням фумару - 19,8\% на суху речовину. Дещо нижчий його вміст (18,2-18,4\% на суху масу) ввиявлено в варіантах, де удобрювали в дозі $\mathrm{P}_{60} \mathrm{~K}_{90}+$ емістим $\mathrm{C}$ та $\mathrm{P}_{60} \mathrm{~K}_{90}+$ фумар. Відомо, що низькі доза азотних добрив незначно впливають на його вміст в кормі, тому що весь Азот використовується для підвищення урожаю. У сухій масі злаково-бобового травостою не спостерігалося суттєвої різниці між варіантами при удобренні в дозі $\mathrm{P}_{30} \mathrm{~K}_{60}$ та $\mathrm{P}_{60} \mathrm{~K}_{90}$. Найнижчий вміст сирого протеїну в кормі виявлено на контрольному варіанті (16,1\% на суху масу).

Вміст білка в сухій речовині досліджуваних травостоїв прямо пропорційний вмісту протеїну на всіх варіантах досліду і складав $81,0-84,4 \%$ від вмісту сирого протеїну. Частка жиру становила $3,1-3,5 \%$ на всіх варіантах, але помітного впливу удобрення і стимуляторів росту на його вміст практично не виявлено, хоча тенденція до збільшення спостерігалася на всіх ділянках досліду порівняно $з$ контролем. Клітковина головна складова частини оболонки клітин рослин. Клітковина забезпечує нормалізацію процесів травлення в шлунку тварин і сприяє засвоєнню поживних речовин корму. Вміст клітковини в сухій масі корму перебував в межах 23,9-25,4\%. Найвища частка іiі відмічена в кормі, вирощеному на варіанті без удобрення (25,4\% на суху масу). Найнижчий вміст клітковини $(23,9 \%)$ у кормі варіанту повного мінерального удобрення $\left(\mathrm{N}_{60} \mathrm{P}_{60} \mathrm{~K}_{90}\right)$. За роки проведення досліджень найменший вміст безазотистих екстрактивних речовин (БЕР) спостерігався в сухій масі на варіанті 3 внесенням азотних добрив в дозі $\mathrm{N}_{60}$ на фоні $\mathrm{P}_{60} \mathrm{~K}_{90} 3$ додаванням фумару.

Таким чином, застосування мінеральних добрив i стимуляторів росту підвищує вміст сирого протеїну в кормі злаково-бобового травостою, поліпшуючи його кормову цінність.

\section{Висновки}

Проведеними нами дослідженнями встановлено, що в умовах Лісостепу західного на еродованих грунтах, виведених під залуження, потрібно використовувати оптимізоване внесення мінеральних добрив i стимуляторів росту на злаково-бобову травосумішку, до складу якої входять люцерна посівна 
(4,4 млн шт./га) + лядвенець рогатий (4,4 млн шт./га) + стоколос безостий (3,4 млн шт./га) + пажитниця багатоукісна (3,4 млн шт./га). За оптимального удобрення $\mathrm{N}_{60} \mathrm{P}_{60} \mathrm{~K}_{90}+$ фумар забезпечили збір сухої маси (7,5 т/га), вихід кормових одиниць становив 5.25 т/га, а перетравного протеїну - 0,82 т/га.

Вміст основних органічних речовин при використанні мінеральних добрив та стимуляторів росту відповідає зоотехнічним нормам годівлі тварин.

При застосування мінеральних добрив і стимуляторів росту в дозі $\mathrm{N}_{60} \mathrm{P}_{60} \mathrm{~K}_{90}+$ фумар корм травостою характеризувався кращими якісними показниками, вміст сирого протеїну становив 19,8\%, клітковини $25,1 \%$ та 3,5\% жиру та покращив його кормову цінність.

\section{References}

Abramovych, S.Ia. (2004). Systema vedennia silskohospodarskoho vyrobnytstva $\mathrm{v}$ hospodarstvakh Rivnenskoi oblasti Rivnenska derzhavna s.-h. stantsiia Tsentr naukovoho zabezpechennia APV Rivnenskoi oblasti. Rivne (in Ukrainian).

Babych, A.O. (1994). Metodyka provedennia doslidiv po kormovyrobnytstvu. Vinnytsia (in Ukrainian).

Biruk, L.A. (1998). Do pytannya proektuvannya protyeroziyno-hruntozakhysnouporyadkovano ahrolandshaftu v umovakh maloho Lisostepu. Ahrokhimiya i gruntoznavstvo, 62, 23-25 (in Ukrainian).

Bohovin, A.V. (2005). Travianysti bioheotsenozy, yikhnie polipshennia ta ratsionalne vykorystannia. K. Ahrarna nauka (in Ukrainian).

Dehodyuk, E.H. (1986). Rol' systemy udobrenyy v povyshenyy y stabylyzatsyy urozhaynosty sel'skokhozyaystvennykh kul'tur. K.: Urozhay (in Ukrainian).

Gulwa, U., Mgujulwa, N., \& Beyene, S.T. (2018). Benefits of grass-legume inter-cropping in livestock systems. African Journal of Agricultural Research, 13(26), 1311-1319. doi: 10.5897/AJAR2018.13172.

Lavres, J., Ferragine, M.D.C., Gerdes, L., Raposo, R.W.C., da Costa, M.N.X., \& Monteiro, F.A. (2004).
Yield components and morphogenesis of Aruana grass in response to nitrogen supply Componentes de produção e morfogênese do capim-Aruana em resposta ao nitrogênio. Scientia Agricola, 61(6), 632639. doi: 10.1590/S0103-90162004000600011.

Lüscher, A., Mueller-Harvey, I., Soussana, F.J., Rees, R.M., \& Peyraud, J.L. (2014). Potential of legumebased grassland-livestock systems in Europe: a review. Grass Forage Sci., 69(2), 206-228. doi: $10.1111 /$ gfs.12124.

Mashchak, Ya.I. (2011). Teoriyi i praktytsi lukivnytstva. Drogobuch: Kola (in Ukrainian).

Peterburhskyy, A.V. (1968). Praktykum po ahronomycheskoy khymyy. M.: Kolos (in Ukrainian).

Ponomarenko, P.S. (1986). Stymulyator rostu Emystym "S" Zakhyst roslyn, 2, 10 (in Ukrainian).

Savchuk, L.K., \& Vyhovsky, I.V. (2018). The influence of single-species crops and their grass mixes on the grass species composition. Scientific Messenger of Lviv National University of Veterinary Medicine and Biotechnologies, 20(89), 3-7. doi: 10.32718/nvlvet8901.

Sayko, V.F. (2000). Vyluchennya $\mathrm{z}$ intensyvnoho obrobitku maloproduktyvnykh zemel' ta yikhnye ratsional'ne vykorystannya. K.: Ahrarna nauka (in Ukrainian).

Stefanyshyn, Ya.S. (2002). Stvorennya siyanykh sinokosiv i pasovyshch yak metod ratsional'noho gruntozakhysnoho vykorystannya erodovanykh skhyliv. Kormy i kormovyrobnytstvo, 48, 75-79 (in Ukrainian).

Volkohon, V.V. (2001). Stymulyatory rostu roslyn yak skladovi tekhnolohiyi ratsional'noho vykorystannya mineral'nykh dobryv. Visnyk Khark. derzh. ahrar. untu, 40-44 (in Ukrainian).

Vyhovsky, I.V. (2018). Removal of nourishing substances with meadow grass harvest. Scientific Messenger of Lviv National University of Veterinary Medicine and Biotechnologies, 20(84), 49-53. doi: 10.15421/nvlvet8409.

Yarmolyuk, M.T. et al. (2010). Ekobiolohichni y ahrotekhnichni osnovy stvorennya trav"yanystykh fitotsenoziv: monohr. L'viv: PAIS (in Ukrainian). 